Original research article

\title{
Specific prescription medications as drivers of out-of-pocket payments and cost-related medication non-adherence in the Czech Republic
}

\author{
Veronika Kočiš Krůtilová *, Dominika Doubková \\ Mendel University in Brno, Faculty of Business and Economics, Brno, Czech Republic
}

\begin{abstract}
Objective: Out-of-pocket payments for medications take a substantial part of Czech households' expenditure for health, which could have a negative impact on medication adherence. Therefore, the objective of this study is to explore the impact of prescription medications related to specific health conditions on patients' out-of-pocket payments and cost-related medication non-adherence.

Methods: We used the data from the second wave of the European Health Interview Survey. Running the analyses in hierarchical stages, our main interest was the influence of medications related to 21 health conditions. A conventional regression method with robust standard errors was used for the investigation of out-of-pocket payments for prescription medication. Predictors of cost-related medication nonadherence were identified using a logistic regression model.

Results: We found that medications for stroke, asthma, myocardial infarction, chronic lung disease, chronic kidney disease, and diabetes contribute to high co-payments. Moreover, cost sharing for stroke, asthma and myocardial infarction medications might have serious implications for desirable consumption as they are associated with medication non-adherence.

Conclusions: We conclude that prescription practices and reimbursement policies in relation to medications for stroke, asthma and myocardial infarction should be carefully explored and physicians should be motivated to prescribe medications covered fully or with low co-payments.
\end{abstract}

Keywords: Czech Republic; Health condition; Medication non-adherence; Out-of-pocket payment; Prescription medication

\section{Introduction}

Cost sharing for medication is a standard feature of health care systems even when packages of covered health care services are very generous. Patients' payments for medication often have the greatest magnitude in households' expenditure for health. Depending on health care system settings and reimbursement policies, as well as on health status and the presence of illnesses, payments for medication might have adverse effects on the desirable medication consumption and equality of access to medication, resulting in more complex implications for the well-being of the population (Gemmill et al., 2008; Sinnott et al., 2013).

Assuming that the demand for pharmaceuticals is derived from the demand for health care, traditional conceptual approaches to the demand for health care (Grossman, 1972) and health care utilisation (Andersen and Newman, 2005) revealed several predictors which have an influence on decisions about health care consumption and access to health care. Among them, health need - in other words, the presence of illness - is one of the fundamental characteristics. Moreover, differences in health care consumption are documented for various health conditions, especially when cost sharing is present (Piette et al., 2006). Previous empirical studies involving medication mostly focused on the explanation of patterns based on various socio-demographic and economic characteristics of the population; some groups vulnerable to diminished access to medication and with high out-of-pocket payments (OOPP) burden have been identified in this regard (Costa-Font et al., 2007; Hennessy et al., 2016; Łuczak and García-Gómez, 2012; McLeod et al., 2011; Morgan and Lee, 2017; Sanwald and Theurl, 2017; Vogler et al., 2015). Nevertheless, studies focusing on the impact of specific medication types on OOPP and access to them are rare.

In the Czech Republic, the overall level of OOPP approximates the European average (15\% of total health expenditure) but payments for medications make up a considerable part. These payments count for more than half of total OOPP which are paid by the Czech population - and as such have a great share in households' expenditure for health (Czech Statistical Office, 2020).

\footnotetext{
* Corresponding author: Veronika Kočiš Krůtilová, Mendel University in Brno, Faculty of Business and Economics, Zemědělská 1, 61300 Brno, Czech Republic; e-mail: veronika.krutilova@mendelu.cz http://doi.org/10.32725/kont.2021.020 
Within this framework our paper contributes to the debate about impacts of OOPP and extends empirical evidence by a particular focus on payments for prescription medication and its affordability and accessibility for Czech patients. The objective of the paper is to explore the impact of prescription medication related to a particular health condition on patients' out-of-pocket payments, and the forfeiting of the desirable consumption due to high co-payments which, to our best knowledge, has not been done yet. Our main research questions are: Which prescription medications are drivers of OOPP for medication? Which prescription medications are associated with cost-related medication non-adherence?

For better understanding of the Czech health care system and its regulations related to medications, we give a brief insight into to the national pharmaceutical policy, reimbursements and cost sharing for medications in the next part of the paper. The paper then continues with a description of the data and methods used. The results of our analyses are introduced in the third part of the paper, firstly showing results for drivers of OOPP for medications and then factors associated with medication non-adherence. We discuss and summarise our results and provide some recommendations in the concluding parts.

\section{National pharmaceutical policy and cost sharing for medication}

The State Institute for Drug Control (SIDC) is the main regulatory body responsible for pharmaceuticals in the Czech Republic. The SIDC sets the maximum prices of pharmaceuticals and reimbursements from public health insurance (applied to reimbursable pharmaceuticals, i.e. prescription medication; the prices of over-the-counter pharmaceuticals are not regulated). The maximum price of a reimbursable medication is set as the average of the three lowest prices in the reference basket and the maximum trade margin. Reimbursement from public health insurance uses the system of reference groups (ca. 200; not always corresponding with the anatomical therapeutic chemical classification - ATC). All pharmaceuticals within the same reference group have the same reimbursement price for the usual daily therapeutic dose. In each pharmaceutical group at least one fully reimbursed medication (most often generic) is available. The reimbursement price is set according to the lowest EU price of a medicinal product within a reference group (Alexa et al., 2015; State Institute for Drug Control, 2018). The list of medications covered by health insurance and its reimbursement is issued every month by the SIDC (State Institute for Drug Control, 2020).

The difference between the maximum and reimbursement price is the co-payment which must be paid out-of-pocket by patients. The co-payment, however, can differ from pharmacy to pharmacy based on the mark-ups used in the distribution chains.

In order to protect patients from high co-payments, an annual limit is put in place. The protective limit has been adjusted several times since its introduction in 2008; for the period of our investigation it was $2500 \mathrm{CZK}$ for patients under 18 years or above 65 years old, and 5000 CZK for other patients (year 2014). However, it is important to note that not all co-payments are included within the limit - only the co-payment corresponding to the cheapest available medication with the same treatment substance and means of application. Moreover, if the same medication is available fully reimbursed from health insurance, the co-payment is not included at all.

\section{Materials and methods}

Data from the European Health Interview Survey (EHIS) is a suitable source for answering our research questions. The EHIS consists of four modules - health status, health care use, health determinants and socio-economic background variables - and targets the population aged at least 15 and living in private households. We used the second wave of the survey which took place in 2014 in the Czech Republic (UZIS CR, 2018). The methodological aspects of the second wave of the survey are discussed elsewhere (Eurostat, 2013).

The subsample for our analysis was only those respondents who had used medication that was prescribed by a physician during the past two weeks $(N=3966)$. This allowed us to focus only on those who had any consumption and deal with relatively recent consumption patterns. This subsample is used as a basis for an investigation of OOPP for prescription medication (defined as co-payments for partly covered medications and direct payments for prescription medications not covered by the health insurance fund but available only on prescription) and cost-related medication non-adherence (derived from a question as to whether a respondent needed to consume prescription medication but could not afford it for financial reasons).

Our analyses start with the investigation of OOPP for prescription medications (in $\mathrm{CZK}$ ) and an estimation of the impact of relevant predictors (OOPP model). The estimation of factors decisive for cost-related medication non-adherence follows in the next step (non-adherence model).

For both models the selection of variables included is based on the concepts of health care (medication) consumption and findings of empirical studies mentioned in the introductory parts of the paper. The final set of variables reflects our research questions, taking into account model diagnostics and respecting the results of goodness-of-fit tests. As the set of influential variables is broad, special attention is paid to possible multicollinearity. The collinearity statistics (tolerance, variance inflation factor, eigenvalue and condition index) are considered (results of multicollinearity diagnostics are displayed in Appendix A).

We ran the analyses in hierarchical stages in order to see the additive influence of the variables; at the same time, this served as a robustness check of our results. Our main interest is the influence of specific types of medication consumed, i.e. prescription medications consumed in relation to a specific health condition, and therefore we observed 21 health conditions and included a variable for other non-specified diseases. The data is derived from the question "Have you taken a prescription medication for this health condition in the last 12 months?". Thus, the first stage included only the dummy variables of these medications. We then extend our analysis by observing other relevant health and health care-related factors. In the second stage we added three categories of self-assessed health (good, satisfactory and poor). The third stage was extended by a dummy variable for outpatient visits (defined as visiting a general practitioner, specialist, dentist or psychiatrist in the last four weeks). In addition, for the OOPP model we included cost-related medication non-adherence as an explanatory variable which might have a relationship with high medication payments. In contrast, in the non-adherence model we included OOPP for medication to confirm this relationship. As the next steps, we controlled for socio-demo- 
graphic and economic determinants. As part of the fourth stage, gender and age (with reference to the protective limit age used as a dummy variable taking value 1 if individuals are older 65) were included. In the fifth stage, we controlled for education recoded into three categories: lower, secondary and higher. In the sixth stage, we included a variable of population density areas distinguishing low density, medium density and high density areas as defined by Eurostat (Eurostat, 2019). Finally, we included a variable of income to control for economic situation and thereby gain a complete model. In our models, income is included as a continuous variable (monthly net income in (ZK) and has been constructed from a proxy question distinguishing 17 income categories. An original income variable was not provided by the data provider due to a huge number of missing responses related to reported exact amounts of income. Considering several options to work with such a huge number of income categories we attributed a threshold amount of each income category as a continuous variable (10 000, 12 000, 14 000, 17 000, 20 000, 22 000, 24 000, 26 000, 29 000, 31 000, 33 000, 35 000, 40 000, 45 000, 52 000; the last two categories between 52-56 000 and over 56000 have been bounded to 56000 CZK). The explanatory variables and sample characteristics are displayed in Table 1.

In this paper, we provide results only for the complete models. The conventional ordinary least square (OLS) regression with robust standard errors is used for the investigation of OOPP for prescription medication. Predictors of cost-related medication non-adherence are identified using a binary logistic regression model. We display the results as average marginal effects (AME's). In Appendix B, the results for the first and the sixth stage are shown. Results of the first stage show pure effects of specific types of medication consumed. The sixth stage presents results of the complete model without controlling for (biased) income to show robustness of estimations. The statistical software IBM SPSS Statistics (version 25) was used for data processing and analyses.

\section{Results}

Firstly, we will present the results for the OOPP model (the complete model). Medications for stroke contribute to the greatest increase in OOPP followed by medications for asthma and myocardial infarction. A slightly lesser burden is found for chronic lung disease - even if the predictive power is rather low. Ranked fourth, taking medications for diabetes has a strong predictive power and contributes to an increase in OOPP. Other significant factors increasing OOPP for medications are cardiovascular diseases (CDV): ischaemic heart disease, hypertension and high blood cholesterol; and musculoskeletal disorders: rheumatoid arthritis, arthrosis and problems in the lumbar and cervical spine. In general, OOPP for prescribed medications increase with worse health; for those having poor health, it is more than twice compared to those with satisfactory health. Having outpatient visits also significantly increases OOPP for prescribed medications.

Those who stated that they could not afford to consume medications for financial reasons face higher OOPP for medications (see Table 2 - OOPP model). This leads us to look at the non-adherence model. Four types of prescription medication increase the probability of having trouble consuming needed medications for financial reasons. Medications for myocardial infarction, stroke and asthma not only increase the OOPP burden but also the probability of cost-related medication non-adherence. Medications for migraine and serious headache are
Table 1. Explanatory variables and sample characteristics $(N=3966)$

\begin{tabular}{lcc} 
Variables' names & $N$ & $\%$ \\
\hline \multicolumn{1}{c}{ categorical variables } & & \\
\hline Prescription medication for: & & 7.8 \\
\hline asthma & 308 & 4.0 \\
\hline chronic lung disease & 158 & 6.4 \\
\hline myocardial infarction & 252 & 11.1 \\
\hline ischaemic heart disease & 440 & 53.8 \\
\hline hypertension & 2135 & 24.1 \\
\hline high blood cholesterol & 955 & 3.7 \\
\hline stroke & 148 & 19.3 \\
\hline arthrosis & 767 & 10.6 \\
\hline rheumatoid arthritis & 422 & 19.8 \\
\hline problems in lumbar spine & 784 & 10.3 \\
\hline problems in cervical spine & 407 & 16.3 \\
\hline diabetes & 647 & 11.6 \\
\hline allergy & 460 & 0.4 \\
\hline cirrhosis & 17 & 4.3 \\
\hline migraine and serious headache & 170 & 6.3 \\
\hline problems with incontinence & 250 & 3.2 \\
\hline chronic kidney diseases & 127 & 5.4 \\
\hline depression & 214 & 5.5 \\
\hline anxiety & 217 & 13.9 \\
\hline thyroid gland & 553 & 334.0 \\
\hline osteoporosis & 674 & \\
\hline other diseases & & \\
\hline Contring & & \\
\hline
\end{tabular}

\begin{tabular}{|lcc|}
\hline Control variables: & & \\
\hline good health & 1576 & 39.7 \\
\hline satisfactory health & 1686 & 42.5 \\
\hline poor health & 704 & 17.8 \\
\hline outpatient visits & 2610 & 65.8 \\
\hline medication non-adherence & 220 & 5.5 \\
\hline male & 1479 & 37.3 \\
\hline female & 2487 & 62.7 \\
\hline age 15 to 64 & 1826 & 46.0 \\
\hline age 65+ & 2140 & 54.0 \\
\hline lower education & 719 & 18.1 \\
\hline secondary education & 2788 & 70.3 \\
\hline higher education & 459 & 11.6 \\
\hline low density & 1577 & 39.8 \\
\hline medium density & 1338 & 33.7 \\
\hline high density & 1051 & 26.5 \\
\hline & mean & standard deviation \\
\hline OopP & 257.2 & 360.7 \\
\hline income & 21743.1 & 10573.3 \\
\hline
\end{tabular}

Note: ${ }^{*}$ mean and standard deviation in CZK. Income constructed from a proxy variable of income categories as the threshold amount of each category. 
Table 2. Determinants of OOPP for prescription medication and cost-related medication non-adherence $(N=3966)$

\begin{tabular}{|c|c|c|c|c|}
\hline \multirow[b]{2}{*}{ Variables' names } & \multicolumn{2}{|c|}{ OOPP model } & \multicolumn{2}{|c|}{ Non-adherence model } \\
\hline & AME & $95 \%$ CI & AME & $95 \%$ CI \\
\hline $\mathrm{OOPP}^{1}$ & \multicolumn{2}{|c|}{ dependent variable } & $0.016^{1 *}$ & {$[0.001 ; 0.032]$} \\
\hline \multicolumn{5}{|l|}{ Prescribed medication for: } \\
\hline asthma & $104.1^{* * *}$ & {$[49.8 ; 158.4]$} & $0.027^{*}$ & {$[0.006 ; 0.048]$} \\
\hline chronic lung disease & $93.6^{*}$ & {$[11.6 ; 175.5]$} & 0.017 & {$[-0.010 ; 0.045]$} \\
\hline myocardial infarction & $105.5^{* * *}$ & {$[52.2 ; 158.8]$} & $0.034^{* *}$ & {$[0.012 ; 0.055]$} \\
\hline ischaemic heart disease & $53.8^{* *}$ & {$[15.4 ; 92.2]$} & 0.009 & {$[-0.010 ; 0.027]$} \\
\hline hypertension & $38.8^{* *}$ & {$[15.5 ; 62.1]$} & $-0.021^{* *}$ & {$[-0.036 ;-0.007]$} \\
\hline high blood cholesterol & $29.9^{*}$ & {$[4.1 ; 55.7]$} & -0.008 & {$[-0.024 ; 0.008]$} \\
\hline stroke & $132.5^{* *}$ & {$[53.3 ; 211.8]$} & $0.034^{* *}$ & {$[0.009 ; 0.059]$} \\
\hline arthrosis & $31.5^{*}$ & {$[0.2 ; 62.8]$} & 0.001 & {$[-0.016 ; 0.017]$} \\
\hline rheumatoid arthritis & $48.6^{*}$ & {$[4.8 ; 92.5]$} & 0.013 & {$[-0.005 ; 0.031]$} \\
\hline problems in lumbar spine & $45.9^{* *}$ & {$[15.8 ; 76.0]$} & 0.011 & {$[-0.006 ; 0.028]$} \\
\hline problems in cervical spine & $44.8^{*}$ & {$[4.5 ; 85.2]$} & 0.004 & {$[-0.016 ; 0.024]$} \\
\hline diabetes & $65.1^{* * *}$ & {$[33.9 ; 96.2]$} & 0.005 & {$[-0.012 ; 0.023]$} \\
\hline allergy & 21.2 & {$[-16.8 ; 59.3]$} & 0.002 & {$[-0.021 ; 0.025]$} \\
\hline cirrhosis & 131.5 & {$[-67.3 ; 330.3]$} & 0.018 & {$[-0.048 ; 0.085]$} \\
\hline migraine and serious headache & 29.2 & {$[-45 ; 103.4]$} & $0.029 *$ & {$[0.004 ; 0.053]$} \\
\hline problems with incontinence & 32.1 & {$[-26.5 ; 90.6]$} & -0.007 & {$[-0.032 ; 0.018]$} \\
\hline chronic kidney diseases & 69.7 & {$[-8.8 ; 148.1]$} & -0.001 & {$[-0.033 ; 0.032]$} \\
\hline depression & -10.1 & {$[-61.2 ; 41.1]$} & 0.024 & {$[-0.002 ; 0.050]$} \\
\hline anxiety & 6.3 & {$[-48.7 ; 61.3]$} & 0.021 & {$[-0.005 ; 0.046]$} \\
\hline thyroid gland & 8.2 & {$[-25.7 ; 42.0]$} & -0.005 & {$[-0.026 ; 0.015]$} \\
\hline osteophorosis & -14.3 & {$[-62.5 ; 33.9]$} & 0.000 & {$[-0.022 ; 0.021]$} \\
\hline other diseases & $62.3^{* * *}$ & {$[32.2 ; 92.4]$} & 0.008 & {$[-0.009 ; 0.025]$} \\
\hline satisfactory health $^{\mathrm{a}}$ & $51.3^{* * *}$ & {$[28.7 ; 73.9]$} & 0.011 & {$[-0.009 ; 0.031]$} \\
\hline poor health ${ }^{\mathrm{a}}$ & $133.1^{* * *}$ & {$[90.9 ; 175.4]$} & $0.032^{* *}$ & {$[0.010 ; 0.054]$} \\
\hline outpatient visits $^{\mathrm{b}}$ & $104.2^{* * *}$ & {$[83.7 ; 124.7]$} & $0.031^{* *}$ & {$[0.013 ; 0.049]$} \\
\hline medication non-adherence $^{c}$ & $73.6^{*}$ & {$[10.4 ; 136.9]$} & \multicolumn{2}{|c|}{ dependent variable } \\
\hline female ${ }^{d}$ & 19.2 & {$[-3.7 ; 42.0]$} & 0.003 & {$[-0.014 ; 0.019]$} \\
\hline age $65+^{e}$ & 25.2 & {$[0.0 ; 50.5]$} & -0.013 & {$[-0.030 ; 0.003]$} \\
\hline secondary education ${ }^{\mathrm{f}}$ & -21.1 & {$[-53.7 ; 11.4]$} & $-0.018^{*}$ & {$[-0.033 ;-0.002]$} \\
\hline higher education ${ }^{f}$ & 2.6 & {$[-40.0 ; 45.1]$} & $-0.038^{*}$ & {$[-0.072 ;-0.004]$} \\
\hline medium density ${ }^{g}$ & $-39.4^{* *}$ & {$[-68.5 ;-10.3]$} & -0.007 & {$[-0.025 ; 0.011]$} \\
\hline low density ${ }^{g}$ & $-30.0 *$ & {$[-59.0 ;-1.1]$} & -0.008 & {$[-0.025 ; 0.009]$} \\
\hline income $^{2}$ & $0.6^{2}$ & {$[-0.6 ; 1.8]$} & $-0.004^{2 * * *}$ & {$[-0.005 ;-0.002]$} \\
\hline
\end{tabular}

Note: AME - average marginal effects (OOPP model in CZK; non-adherence model in probabilities).

${ }^{*} p<0.05,{ }^{* *} p<0.01,{ }^{* * *} p<0.001$.

CI - confidence interval.

${ }^{1} \mathrm{AME}$ adjusted for an increase in OOPP by $1000 \mathrm{CZK} ;{ }^{2} \mathrm{AME}$ adjusted for an increase in income by $1000 \mathrm{CZK}$.

Reference categories: ${ }^{\mathrm{a}}$ good health; ${ }^{\mathrm{b}}$ no outpatient visit in last 6 months; ${ }^{\mathrm{c}}$ no medication non-adherence due to financial situation; ${ }^{\mathrm{d}}$ male; ${ }^{\mathrm{e}}$ individuals younger than 65 ; ${ }^{\mathrm{f}}$ lower education; $\mathrm{g}$ high density. 
also identified as a risk factor for medication non-adherence although they are not identified as a driver of high OOPP. Regarding other health (care) related variables, being in poor health and having outpatient visits is related to a significant increase in the probability of facing medication non-adherence. Increasing OOPP for prescription medications show a relatively small but positive incremental effect on the probability of medication non-adherence (e.g. an increase in OOPP by $1000 \mathrm{CZK}$ increases the probability of non-adherence by 1.6 percentage points).

Finally, we briefly mention results for other control variables. Education is a significant predictor for medication non-adherence. Thus, the higher the education the lower the probability of medication non-adherence is. Population density areas play a role only for OOPP for medication; those living in areas with higher density have higher OOPP for medication. The result for our income proxy variable suggests that income is a significant predictor for medication non-adherence, i.e. an increase in income decreases the probability of medication non-adherence.

\section{Discussion}

In essence, prescription medications are recognised as medications with particular importance for population health. Providing that these medications are properly prescribed, their consumption is inherently desirable. However, our findings suggest that the costs of some prescription medications not only contribute to high OOPP for medications but are also related to medication non-adherence.

Namely, prescription medications consumed in relation to myocardial infarction, stroke and asthma might push Czech patients into serious risk. Currently, the number of items of prescription medications distributed in the Czech Republic is large. However, looking at a list of the 50 most frequently prescription medications published by the largest health insurance fund, the listed medications related to myocardial infarction (from the ATC C07, C09) have significant co-payments. For the majority of them, the co-payment is included in a very low amount in the annual protective limit or is not included at all (VZP CR, 2020). With reference to the list, lower co-payments can be found for medications related to stroke (ATC B01) compared to myocardial infarction; however, a much broader scope of medications can be prescribed to treat related health problems. The most frequently prescribed medication for asthma also belongs to a group of medications with relatively high co-payments (ATC R03, R06) and is only partly included in the limit. Taking into account that the majority of these types of medication must be consumed for the duration of a person's life, a related pharmacotherapy and reimbursement policy should be further investigated if we want to secure full access to needed medications.

Additionally, we would like to briefly discuss our findings for outpatient visits. It seems that Czech patients often leave physicians' surgeries with a prescription which has an impact on the amount of OOPP paid by patients, which in turn is also related to medication non-adherence. On the one hand, we can argue that this is not surprising as prescription medication must be prescribed by a physician and often a visit is necessary (even if e-prescription is more and more common). On the other hand, this might imply inappropriate prescribing behaviour as a physician always has the option of prescribing a generic medicine. Another possibly related issue is overmed- ication. It was shown elsewhere that the demand for prescription medications results from the physician-patient agency relationship (Costa-Font et al., 2007). Thus, to lower the burden and improve access to prescription medications, prescription practice should be further explored.

Previous research showed that the consumption of prescription medications is related to lower socio-economic groups and medication non-adherence is higher among lower income individuals (Morgan and Lee, 2017; Vogler et al., 2015). In our study, a significant relationship between education and medication non-adherence might refer not only to social status but also economic situation. Unfortunately, we did not obtain exact data about income of respondents from the data provider - the Institute of Health Information and Statistics of the Czech Republic - to control for the income situation properly. To deal with this issue we had to construct a proxy variable from income categories. Therefore, findings about income are limited in our study and serve only for control purposes in the regression analyses. We recognise biased information about income as a limitation of our study. Conclusions about income should not be drawn for other research purposes. Nonetheless, as shown in the appendices, exclusion of income as a control variable in the regression models did not affect our findings about impacts of prescription medications.

Finally, we must acknowledge that we cannot distinguish between co-payments for partly covered medications and direct payments for medications not covered by the health insurance fund but available only with a prescription (e.g. contraception pills). Furthermore, the group of medications for other diseases shows a significant relationship to OOPP but these diseases are not specified in the survey. In addition, we also had to deal with certain time discrepancies in the survey questions. We are aware of the fact that some reporting biases such as under- or overestimation of OOPP, or misclassification of medications related to particular health conditions might be present. However, even if administrative data from relevant bodies would provide exact information on medication types or ATC, they would fail to account for other important socio-economic determinants, self-perceived access to health care and most importantly exact amounts of OOPP (co-payments) as pharmacies are obliged to report only co-payments counting towards the protective limit.

\section{Conclusions}

Our study suggests that consideration of specific types of prescription medications in the evaluation of access to these medications is a desirable feature of health care policies. To focus on the Czech Republic, firstly prescription practices and reimbursement policies in relation to medications for stroke, asthma and myocardial infarction should be further carefully explored based on the administrative data of health insurance companies. As the second step, health insurance funds should better motivate physicians to prescribe medications which are covered fully or with low co-payments.

\section{Acknowledgements}

We gratefully acknowledge the data from the European Health Interview Survey (EHIS 2014) provided by the Institute of Health Information and Statistics of the Czech Republic https://ehis.uzis.cz/index-en.php?pg=ehis-2014 for our analyses. 


\section{Funding}

This research did not receive any specific grant from funding agencies in the public, commercial, or not-for-profit sectors.

\section{Research ethics approval}

The study does not require any human/animal subjects to acquire ethical approval.

\title{
Conflict of interests
}

The authors declare that they have no conflict of interests.

\section{Léčiva na předpis jako hnací motor výdajů pacientů za léčiva a odkládání jejich spotřeby v České republice}

\begin{abstract}
Souhrn
Cíl: Výdaje pacientů za léky tvoří značnou část celkových výdajů za zdraví, což může mít negativní dopad na žádoucí spotřebu daných léčiv. Cílem této studie je proto zhodnotit dopad vybraných léčiv na předpis na výdaje pacientů za léčiva a odkládání jejich spotřeby právě z důvodů vysokých výdajů za tato léčiva.

Metodika: Pro studii jsou použita data z druhé vlny Evropského výběrového šetření o zdraví. Předmětem výzkumu jsou léčiva na předpis vztažená k 21 zdravotním potížím. Pro analýzu výdajů za léčiva byla použita konvenční regresní metoda s robustními standardními chybami. Faktory rozhodující pro odkládání spotřeby léčiv byly identifikovány prostřednictvím logistického regresního modelu.

Výsledky: Léky na mozkovou mrtvici, astma, infarkt myokardu, chronickou obstrukční plicní nemoc, chronické onemocnění ledvin a cukrovku významně přispívají k vysokým doplatkům za léky. Výdaje za léky na mozkovou mrtvici, astma a infarkt myokardu mohou mít navíc významné dopady na spotřebu léčiv, nebot' jsou statisticky významným faktorem pro odkládání spotřeby léčiv. Závěr: Preskripce a úhrada léčiv ze zdravotního pojištění by měla být přezkoumána zejména ve vztahu k léčivům předepisovaným $\mathrm{v}$ souvislosti s mozkovou mrtvicí, astmatem a infarktem myokardu. Zároveň by také měla být zvýšena motivace lékařu k předepisování léčiv, která jsou bud' hrazena plně ze zdravotního pojištění, nebo mají nižší doplatky.
\end{abstract}

Klíčová slova: Česká republika; léky na předpis; odkládání spotřeby léčiv; výdaje pacientů na zdraví; zdravotní potíže

\section{References}

1. Alexa J, Rečka L, Votápková J, van Ginneken E, Spranger A, Wittenbecher F (2015). Czech Republic: Health system review. Health Systems in Transition 17(1): 1-165.

2. Andersen R, Newman JF (2005). Societal and individual determinants of medical care utilisation in the United States. Milbank Quarterly 83(4): 1-28. DOI: 10.1111/j.14680009.2005.00428.x.

3. Costa-Font J, Kanavos P, Rovira J (2007). Determinants of out-of-pocket pharmaceutical expenditure and access to drugs in Catalonia. Applied Economics 39(5): 541-551. DOI: $10.1080 / 00036840500438947$.

4. Czech Statistical Office (2020). Household Consumption Expenditures - 2018. [online] [cit. 2020-01-23]. Available at: https://www.czso.cz/csu/czso/household-consumptionexpenditures-2018

5. Eurostat (2013). European Health Interview Survey (EHIS wave 2) - methodological manual. Luxembourg: Publications Office of the European Union, 193 p. DOI: 10.2785/43280.

6. Eurostat (2019). RAMON - Reference and Management of Nomenclatures. [online] [cit. 2019-11-22]. Available at: https://ec.europa.eu/eurostat/ramon/miscellaneous/index. cfm?TargetUrl=DSP_DEGURBA

7. Gemmill MC, Thomson S, Mossialos E (2008). What impact do prescription drug charges have on efficiency and equity? Evidence from high-income countries. Int J Equity Health 7: 12. DOI: 10.1186/1475-9276-7-12.

8. Grossman M (1972). On the Concept of Health Capital and the Demand for Health. J Politic Econ 80(2): 223-255. DOI: $10.1086 / 259880$.

9. Hennessy D, Sanmartin C, Ronksley P, Weaver R, Campbell D, Manns B, et al. (2016). Out-of-pocket spending on drugs and pharmaceutical products and cost-related prescription nonadherence among Canadians with chronic disease. Health Rep 27(6): 3-8.

10. Łuczak J, García-Gómez P (2012). Financial burden of drug expenditures in Poland. Health Policy 105(2-3): 256-264. DOI: 10.1016/j.healthpol.2012.01.004.
11. McLeod L, Bereza G, Shim M, Grootendorst P (2011). Financial burden of household out-of-pocket expenditures for prescription drugs: cross-sectional analysis based on national survey data. Open Med 5(1): e1-e9.

12. Morgan SG, Lee A (2017). Cost-related non-adherence to prescribed medicines among older adults: A cross-sectional analysis of a survey in 11 developed countries. BMJ Open 7(1): e014287. DOI: 10.1136/bmjopen-2016-014287.

13. Piette JD, Heisler M, Horne R, Caleb Alexander GC (2006). A conceptually based approach to understanding chronically ill patients' responses to medication cost pressures. Soc Sci Med 62(4): 846-857. DOI: 10.1016/j.socscimed.2005.06.045.

14. Sanwald A, Theurl E (2017). Out-of-pocket expenditures for pharmaceuticals: lessons from the Austrian household budget survey. Eur J Health Econ 18(4): 435-447. DOI: 10.1007/ s10198-016-0797-y.

15. Sinnott S-J, Buckley C, O'Riordan D, Bradley C, Whelton H (2013). The Effect of Copayments for Prescriptions on Adherence to Prescription Medicines in Publicly Insured Populations; A Systematic Review and Meta-Analysis. PLoS One 8(5): e64914. DOI: 10.1371/journal.pone.0064914.

16. State Institute for Drug Control (2018). Regulation of prices and reimbursements for pharmaceuticals. [online] [cit. 202001-23]. Available at: http://www.sukl.eu/medicines/regulationof-prices-and-reimbursements-for-pharmaceuticals

17. State Institute for Drug Control (2020). List of reimbursed medicinal products. [online] [cit. 2020-01-23]. Available at: http://www.sukl.eu/sukl/list-of-reimbursed-medicinal-products

18. UZIS CR (2018). European Health Interview Survey (EHIS 2014). [online] [cit. 2019-01-30]. Available at: https://ehis.uzis. cz/index-en.php?pg=ehis-2014

19. Vogler S, Österle A, Mayer S (2015). Inequalities in medicine use in Central Eastern Europe: An empirical investigation of socioeconomic determinants in eight countries. Int J Equity Health 14: 124. DOI: 10.1186/s12939-015-0261-0.

20. VZP CR (2020). Ročenka za rok 2018 [Annual Book 2018]. [online] [cit. 2020-01-29]. Available at: https://media.vzpstatic. cz/media/Default/rocenky/rocenka_vzp_2018.pdf 